\title{
DOCTRINE OF CONDONATION: CHALLENGES IN THE MANAGEMENT OF DISCIPLINARY CASES IN PUBLIC UNIVERSITY
}

Fariza Romli, Senior Lecturer, College of Law, Government and International Studies, Universiti Utara Malaysia, Malaysia.

E-mail: arfariza@uum.edu.my

Nuarrual Hilal Md Dahlan Associate Professor, School of Law, UUM COLGIS, Universiti Utara Malaysia, Malaysia.

E-mail: nuarrualhilal@uum.edu.my

Rusniah Ahmad, Associate Professor, School of Law, UUM COLGIS, Universiti Utara Malaysia Malaysia, Malaysia. E-mail: rusniah@uum.edu.my

Abstract: The disciplinary committee in public university carry a huge responsibilities to uphold justice to the employer as well as to the employee in handling the disciplinary cases. One of the hindrance faced by the committee is the issue on doctrine of condonation as a waiver. Thus, it is important to understand what is doctrine of condonation in order to identify, prevent, control and deal with it when used as a defense by the employee to prevent him from being punished by the authorities. Therefore, this paper will examine the definition of the doctrine of condonation, explain the protection under Statutory Bodies (Discipline and Surcharge) Act 2000 [Act 605] with regards to condonation, identifies the elements of a waiver by looking at the application of the doctrine by the court and the implications of the doctrine as a challenge in disciplinary cases in public universities. The methodology used is based on library research with an analysis of the legal acts, regulations and case law. The author found that the disciplinary action should be done effectively by the authorities to make sure that action is taken within reasonable time. Lack of certain rules or procedure can cause detriment in handling the issues on condonation.

Keywords: doctrine of condonation, termination of service, public university, Malaysia. 


\section{INTRODUCTION}

Generally, since 1889 the doctrine of condonation has been recognized at common law as a claim available to employees in wrongful dismissal suits ${ }^{1}$. The doctrine originated from common law system and has been established in a few common law countries such as Australia, New Zealand, India, South Africa, Hong Kong as well as Malaysia. ${ }^{2}$ It is often designated as a 'waiver' of the employer's right to punish for misconduct ${ }^{3}$, especially in disciplinary cases. Therefore, this paper will examine the definition of the doctrine of condonation, explain the protection under Statutory Bodies (Discipline and Surcharge) Act 2000 [Act 605] with regards to condonation, since this act is the main law to regulate and discipline its employees in public universities. This paper will also identify the elements of a waiver by looking at the application of the doctrine by the court and the implications of the doctrine as a challenge in disciplinary cases in Malaysian public universities. Doctrine of condonation is also among the doctrine as applied to ensure procedural fairness in disciplinary cases.

\section{DEFINITION OF DOCTRINE OF CONDONATION}

There is no specific or satisfactory definition to explain the meaning of doctrine of condonation in every circumstances of the disciplinary cases ${ }^{4}$. Thus, this paper tries to define this doctrine base on the definition given from the main dictionaries and also on decided cases from Malaysia as well as from other countries.

1 Marcotte, Aaron P, 'Can Employers Forgive and Forget? : Employer Condonation and Wrongful Dismissal In Canada'. (1998) 8 Windsor Review of Legal \& Social Issues. Issues 3.pg 1

2 National Union of Plantation Workers v Kumpulan Jerai Sdn. Bhd., Rengam (2000) 2 AMR 1387 at pg. 1396

3 Haidar Mohd Noor JCA (as his Lordship then was) in National Union of Plantation Workers V Kumpulan Jerai Sdn. Bhd., Rengam (2000) 2 AMR 1387 at pg 1396 and Abdul Majid, 'Condonation as waiver of the employer's right to punish misconduct’. (1996) 2 Malayan Law Journal, pg. xvii.

4 _ 'Isu Doctrine of Condonation Dalam Pengendalian Tatatertib', Persidangan ke III Pengerusi-Pengerusi Lembaga Tatatertib Perkhidmatan Awam, 6-8 September 2006, The Puteri Pacific Johor Bahru, Anjuran Suruhanjaya Perkhidmatan Awam dan Jabatan Perkhidmatan Awam, pg 3. 
According to The Oxford English Dictionary ${ }^{5}$, 'condone'- is to forgive or overlook (an offence), so as to treat it as non-existent; to forgive tacitly by not allowing the offence to make any difference in one's relation with the offender. Black's Law Dictionary define 'condonation' as - a victim's express or implied forgiveness of offence, specially by treating the offender as if there had been no offence $^{6}$. According to Webster's New World Law Dictionary ${ }^{7}$, 'condonation' means - the forgiveness, purposeful disregard, or tacit approval by a victim of another's illegal or objectional act, especially by treating the other person as if nothing happened.

Reference can also be made to the Halsbury's Laws of Malaysia on the subject of condonation which reads as below:

"Condonation arises when an employer with full knowledge of a servant's misconduct, elects to continue him in service. Where misconduct has been condoned, it may not be relied on by the employer to dismiss a workman unless there are subsequent acts of misconduct".

A few cases has been decided in Malaysia and also in other countries which can make us understand the meaning of doctrine of condonation. In Malaysia, like in the case of Azman bin Abdullah $v$ Ketua Polis Negara (1997) 1 MLJ 263, Abdul Malik Ahmad JCA (as his Lordship then was) allowed the appeal of a sub-inspector who was demoted, based on the doctrine of condonation. Reference was made in that case to District Council, Amraoti v Vithal Vinayak, AIR 1941 Nagpur 125 where the court said:

"Once a master has condoned any misconduct which would have justified dismissal or a fine, he cannot after such condonation go back upon his election to condone and claim a right to dismiss his (the servant) or impose a fine or any other punishment in respect of the offence which has been condoned".

Simpson J. \& Weiner E. , The Oxford English Dictionary (second edition),(1989), Clarendon Press, Oxford.

6 Bryan A. Garner, Black's Law Dictionary (eight edition), West Group (2004), U.S. Wild, Susan Ellis, Webster's New World Law Dictionary (second edition), (2010), Wiley Publishing Inc., New Jersey. 
In National Union of Plantation Workers $v$ Kumpulan Jerai Sdn Bhd, Rengam (2000) 2 AMR 1387, Haidar Mohd Noor JCA (as his Lordship then was) expressed his opinion at page 1396 as below:

"we agree to the principle of condonation as a waiver of the employer's right to punish for misconduct."

A few cases decided by the court in Canada explained about the doctrine of condonation, like in the case of McIntyre $v$ Hockin (1889) 16 O.A.R 498, the judge mentioned that:

"When an employer becomes aware of misconduct on the part of his servant, sufficient to justify dismissal, he may adopt either of two courses. He may dismiss, or he may overlook the fault. But he cannot retain the servant in his employment, and afterwards at any distance of time turn him away...if he retains the servants in his employment for any considerable time after discovering his fault, that is condonation, and he cannot afterwards dismiss for that fault without anything new."

Another case is Tracey $v$ Swansea Construction Co. Ltd. [1965] 1 O.R. 203, in this case the judge said:
"While a master, upon becoming aware of a servant's misconduct sufficient to justify immediate dismissal, is entitled to a reasonable time to decide whether or not he will dismiss, yet, if he retains the servants for any considerable time after discovering his fault, he condones such conduct and is not entitled subsequently to dismiss him on account of what which he has condoned.

Base on the interpretation of the word condone or condonation in few major dictionaries as well as the decision of the judges in a few decided cases, we can conclude that the meaning of doctrine of condonation can be generally describes as permission granted to an employee retrospectively to cover a breach of conduct or prior misconduct as well as prospectively. Such retrospective permission 
is called condonation. An employer who excuses or condones the employee's breach of duty with full knowledge, cannot thereafter punish the employee unless the same duty is breached again.

\section{THE ELEMENTS OF THE DOCTRINE}

By looking at the meaning of this doctrine above, impliedly some key elements of the doctrine can be identified. Firstly, the employer has full knowledge of the employee's misconduct, secondly, inordinate delay and lastly, express or implied behaviour of the employer to condone misconduct. These important elements of the doctrine also mentioned in Halsbury's Laws of Malaysia as mention above when we discussed about the definition of the doctrine.

\section{Employer Has Full Knowledge of the Employee's Misconduct.}

The doctrine of condonation is not affected unless it is proceeded by knowledge of the employer. The misconduct or breach of any disciplinary rule must be in 'actual knowledge' and not the 'constructive knowledge' of the employer. ${ }^{8}$ This means, the employer has acquired full knowledge of the nature, fact and circumstances of an employee's offence.

The Federal Court in Ranjit Kaur a/p S. Gopal Singh v Hotel Excelsior (M) Sdn $\mathrm{Bhd}^{9}$ gave comment on the wrong application of the doctrine of condonation by Industrial Court when it stated that: "another error on the part of the Industrial Court was when it concluded that the respondent had condoned the appellant's conduct in relation to her coming to work late. Clearly the Industrial Court has misapplied the doctrine of condonation. The doctrine of condonation would only come into play if the respondent had been fully aware of the applicant's late coming and nonetheless elected to do nothing about it. However, the respondent had adduced evidence that the appellant had been warned about such conduct previously".

\footnotetext{
8 _ 'Isu Doctrine of Condonation Dalam Pengendalian Tatatertib', Persidangan ke III Pengerusi-Pengerusi Lembaga Tatatertib Perkhidmatan Awam, 6-8 September 2006, The Puteri Pacific Johor Bahru, Anjuran Suruhanjaya Perkhidmatan Awam dan Jabatan Perkhidmatan Awam, pg 21.

9 [2010] 8 CLJ 629 at pg. 641
} 
Therefore, condonation does not occur if the employer does not know that the misconduct has taken place until later when the employer immediately takes action to investigate. In brief, condonation occurs when an employee commits a misconduct which comes to the knowledge of the employer and not merely base on presumption that the employer has condoned the employee's misconduct, before any disciplinary action is taken. ${ }^{10}$

\section{Inordinate Delay}

An employee who becomes aware of an employee's misconduct has to choose between the two alternatives, either to discipline the employee for breaching the contract of employment, or forgiving him. This is called in law an 'election'. An employer need to make his election immediately, but if he takes more than what is, in the circumstances a reasonable time, the law will take the matter out of his hands by deeming him to have elected to waive his right by forgiving the employee and not to discipline the employee for breaching the contract of employment. ${ }^{11}$ Thus, a condonation is at law, a 'waiver' of a right. ${ }^{12}$

The elemen of delay is expressly stated by Court of Appeal in the case of M Sentivelu R Marimuthu v Public Service Commission Malaysia \& Anor $^{13}$, where in this case Gopal Sri Ram JCA explained that:

“....the fact that the General Orders Cap 'D' does not prescribed a time limit does not mean that a disciplinary hearing in respect of charges of misconduct brought no matter how long after the event may be upheld as being procedurally fair. It all depends on the fact of each case. In particular it depends on a number of factors including, the nature of the charge, the length of the

10 Alfred Charles, A-Z Guide to Employment Practice In Malaysia, Second Edition, ( 2009) CCH Asia, pg.13-14.

11 Per Lord Blackburn in Scarf v Jardine [1881-5] ALL ER Rep 651 at pg. 658

12 Abdul Majid, 'Condonation as waiver of the employer's right to punish misconduct’. (1996) 2 Malayan Law Journal, pg. xvii at xx.

13 M Sentivelu R Marimuthu v Public Service Commission Malaysia \& Anor [2005] 3 CLJ 778 at pg. 783 
delay, the reasons for the delay the opportunity which the employee had to evidentially meet the accusation leveled at him. In the absence of any reasonable explanation, the longer the delay, the more difficult it would be for the disciplining body to justify the proceedings against the employee. Further, long delay may, when coupled with some other circumstances, amount to strong evidence of condonation on the part of the employer of the employee misconduct".

According to Gopal Sri Ram JCA above, the inordinate delay here means unreasonable delays and do not have strong reasons to defense that can exceed a reasonable period to take action. If the law is silent on time limit, it doesn't mean that the authority can freely decide the time to take action which is procedurally unfair to the employees and can cause injustice.

In Sentivelu's case, the delay of seven years on the part of the respondents in charging him for misconduct. In McCalla $\mathrm{v}$ Disciplinary Committee of the General Legal Council ${ }^{14}$, there was a delay of two years between the issue of the complaint and the notice of the intended hearing against him and in Azman bin Abdullah v Ketua Polis Negara ${ }^{15}$, there was a delay between two to five years, that is between the commission of the several acts of misconduct and the holding of the inquiry which can amount to condonation by the employer.

\section{Express or Implied Behavior of the Employer to Condone Misconduct}

Doctrine of condonation also refer to the behaviour of the employer by which he excused or condoned or waive the employee either expressly or impliedly by allowing the employee to continue in employment. ${ }^{16}$ This last element is best to refer to the case of Telekom Malaysia Bhd. V Subramaniam Ahyahio ${ }^{17}$ where the judge

\footnotetext{
14 [1999] 1 LRC 195

15 [1997]1CLJ 257

16 R.M.P, The Condonation Doctrine: The Search for A Rationale, University of Pennsylvania Law Review, Vol 110, No 6.(April 1962) pp. 879-894 at pg 888.

17 [1998]1ILR 476 at pg. 479
} 
said that, while the claimant was still waiting for the result of the domestic inquiry, he was asked to report for duty. In fact the company had condoned his act when it did not take further action against the claimant after receiving a reply from the show cause letter. The fact that the company informed the claimant to continue work after the domestic inquiry is further testimony that the company had waived its right to punish the claimant.

\section{The University Law and the Implications of the Doctrine}

The powers of the public universities to discipline and regulate its employees are derived from many laws and regulations, the primary law is Statutory Bodies (Discipline and Surcharge) Act 2000 [Act 605], which explain inter alia the code of conduct of the employees, the disciplinary procedures and also the disciplinary punishment. ${ }^{18}$ Other general laws for example, Universities and Universities College Act 1971, Federal Constitutions, Official Secrets Act 1972, Contract Act and government contract Act 1949 which have indirect bearing on the universities powers, procedures, duties and immunities. ${ }^{19}$

Generally Act 605 has no express provisions or authorizations for the condonation doctrine. Act 605 also never prescribe a time limit for taking disciplinary action. But, as mentioned earlier, the doctrine of condonation is also among the doctrine as applied to ensure procedural fairness in disciplinary cases. ${ }^{20}$ So, if there is a lacuna in the relevant law, then the principle under common law will take place to make sure justice is done. We also can refer to M Sentivellu case above when the court decide that although the current law never mention about time limit for taking disciplinary action, but still the disciplinary committee cannot delay the process

\footnotetext{
Second Schedule of the Statutory Bodies ( Discipline and Surcharge) Act 2000 [Act 605]

19 Shad Saleem Faruqi, The Laws Relating to Staff Discipline at Malaysian Universities, Seminar Perundangan Sumber Manusia, 13July 2011, Universiti Sains Malaysia.

20 'Isu Doctrine of Condonation Dalam Pengendalian Tatatertib', Persidangan ke III Pengerusi-Pengerusi Lembaga Tatatertib Perkhidmatan Awam, 6-8 September 2006, The Puteri Pacific Johor Bahru, Anjuran Suruhanjaya Perkhidmatan Awam dan Jabatan Perkhidmatan Awam, pg 1.
} 
which is not procedurally fair to the employee. The same reason applies to Act 605 for public universities.

The disciplinary committee is bound by statutory procedures and natural justice requirements ${ }^{21}$. The most common type of condonation which also happened in the management of disciplinary cases in university is the inordinate delay in taking the disciplinary action. This happened where the employer is aware of the misconduct but does nothing and continues to employ the employee. By not giving proper notice and follow exactly the statutory procedures might lead to the employee believe that their misconduct was condone by the employer. The example of misconducts are breach of study leave agreement, where the employee fails to return on duty, absence without leave or conduct himself in such manner that can bring disrepute or discredit to the University, irresponsible and negligent in performing his duties.

Employees in public university can use doctrine of condonation as their defense if there is a considerable delay by the university in taking the disciplinary action when the university know about the misconduct. They believe that the university has forgiven, approved or sanctioned their wrongdoing. Employees who breach the study leave agreement also believe that the university has condone their misconduct or wrongdoing when they continue their work as usual and being given an administrative task in the university. The university is considered had waived its right to punish the employee.

\section{FINDING AND RECOMMENDATIONS}

Doctrine of condonation is truly a challenge in the management of disciplinary cases in public university. If all elements of condonation as prescribe above are fulfilled, then the employee can use it as a defense to prevent him from being punished by the authorities. The long delay coupled with other circumstances may amount to strong evidence of condonation on the part of the university of the employee's misconduct.

${ }^{21}$ Natural justice is a Common Law principle that is audi alteram partem rule (right to be heard) and the rule against bias. 
Although the disciplinary authority and the secretariat are bound to follow the statutory procedures, in this case the Statutory Bodies (Discipline and Surcharge) Act 2000 [Act 605], but there is no express provisions about the time limit as to when the disciplinary action can be taken against the errant employee.

Therefore in this situation, the author found that the disciplinary action should be done effectively and thoroughness by the authorities in each and every cases because it could involve legal implications. The action must be taken within reasonable time and the law should be improved because lack of certain rules or procedure can cause detriment in handling the issues on condonation.

If legal action is taken was flawed in which the doctrine of condonation may apply, it is fruitless and can cause detrimental and shameful to the government in terms of time and cost including the cost of compensations to the employee if the court decision is in his favor.

\section{BIBLIOGRAPHY}

'Isu Doctrine of Condonation Dalam Pengendalian Tatatertib', Persidangan ke III Pengerusi-Pengerusi Lembaga Tatatertib Perkhidmatan Awam, 6-8 September 2006, The Puteri Pacific Johor Bahru, Anjuran Suruhanjaya Perkhidmatan Awam dan Jabatan Perkhidmatan Awam.

Abdul Majid. 'Condonation as waiver of the employer's right to punish misconduct'. (1996) 2 Malayan Law Journal, pg. xvii. Alfred Charles. A-Z Guide to Employment Practice In Malaysia, Second Edition, ( 2009) CCH Asia, pg.13-14.

Azman bin Abdullah v Ketua Polis Negara [1997]1CLJ 257.

Bryan A. Garner. Black's Law Dictionary (eight edition), West Group (2004), U.S.

Marcotte, Aaron P. 'Can Employers Forgive and Forget? : Employer

Condonation and Wrongful Dismissal In Canada'. (1998) 8

Windsor Review of Legal \& Social Issues. Issues 3.pg 1.

McCalla v Disciplinary Committee of the General Legal Council [1999] 1 LRC 195. 
M Sentivelu R Marimuthu v Public Service Commission Malaysia \& Anor [2005] 3 CLJ 778.

National Union of Plantation Workers v Kumpulan Jerai Sdn. Bhd., Rengam (2000) 2 AMR 1387.

Ranjit Kaur a/p S. Gopal Singh v Hotel Excelsior (M) Sdn Bhd [2010] 8 CLJ 629.

R.M.P, The Condonation Doctrine: The Search for A Rationale, University of Pennsylvania Law Review, Vol 110, No 6.(April 1962) pp. 879-894.

Scarf v Jardine [1881-5] ALL ER Rep 651 at pg. 658.

Simpson J., \& Weiner E. , The Oxford English Dictionary (second edition),(1989), Clarendon Press, Oxford.

Shad Saleem Faruqi. The Laws Relating to Staff Discipline at Malaysian Universities, Seminar Perundangan Sumber Manusia, 13July 2011, Universiti Sains Malaysia.

Telekom Malaysia Bhd. V Subramaniam Ahyahio [1998]1ILR 476.

Wild, Susan Ellis. Webster's New World Law Dictionary (second edition), (2010), Wiley Publishing Inc., New Jersey. 